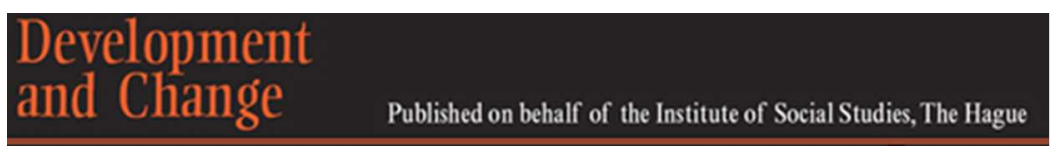

\title{
Social Policy for Mature Neoliberalism: The Bolsa Família Programme in Brazil
}

\begin{tabular}{|r|l|}
\hline Journal: & Development and Change \\
\hline Manuscript ID: & Draft \\
\hline Manuscript Type: & Original Article \\
\hline Date Submitted by the Author: & n/a \\
\hline Complete List of Authors: & Saad Filho, Alfredo; SOAS, University of London, Development Studies \\
\hline Keywords: & $\begin{array}{l}\text { Social policy < General, neoliberalism, Poverty < General, Inequality < } \\
\text { General, conditional cash transfers, Bolsa Familia }\end{array}$ \\
\hline & $\begin{array}{l}\text { The Brazilian Programa Bolsa Família (PBF) is the largest and most } \\
\text { successful conditional cash transfer programme in the world. Examination } \\
\text { of its conceptual foundations, roots, key features, impact and limitations } \\
\text { shows that PBF belongs within a narrow neoliberal social policy framework. } \\
\text { PBF distributes conditional and very small tax-funded benefits to the } \\
\text { 'deserving destitute'. In doing this, it provides marginal support to the } \\
\text { poorest of the poor; at the same time, it subsidises low wages and helps to } \\
\text { perpetuate the structures of reproduction of poverty and inequality which it } \\
\text { purports to address. A pro-poor and democratic alternative is outlined, } \\
\text { which can lead to faster improvements in living conditions and support the } \\
\text { expansion of citizenship. }\end{array}$ \\
\hline & \multicolumn{2}{|l}{} \\
\hline
\end{tabular}




\title{
Social Policy for Mature Neoliberalism:
}

\section{$\underline{\text { The Bolsa Família Programme in Brazil }}^{1}$}

\author{
Alfredo Saad Filho \\ Department of Development Studies \\ SOAS, University of London \\ as59@soas.ac.uk
}

\begin{abstract}
$\underline{\text { Abstract }}$
The Brazilian Programa Bolsa Família (PBF) is the largest and most successful conditional cash transfer programme in the world. Examination of its conceptual foundations, roots, key features, impact and limitations shows that PBF belongs within a narrow neoliberal social policy framework. PBF distributes conditional and very small tax-funded benefits to the 'deserving destitute'. In doing this, it provides marginal support to the poorest of the poor; at the same time, it subsidises low wages and helps to perpetuate the structures of reproduction of poverty and inequality which it purports to address. A pro-poor and democratic alternative is outlined, which can lead to faster improvements in living conditions and support the expansion of citizenship.
\end{abstract}

Keywords: Neoliberalism, poverty, inequality, social policy, conditional cash transfers, Bolsa Família.

Wordcount: 9,400 .

\footnotetext{
${ }^{1}$ I am grateful to Alison Ayers, Michela Cerimele, Neil Coleman, Ben Fine and Maria de Lourdes R. Mollo for their contributions to previous versions of this paper. The usual disclaimers apply.
} 


\section{Social Policy for Mature Neoliberalism:}

The Bolsa Família Programme in Brazil

The Brazilian Programa Bolsa Família (Family Grant, PBF) is the most successful conditional cash transfer programme (CCT) in the world. PBF is alleged to have made a significant contribution to the reduction in poverty and the distributional improvements in the country over the past decade, and it has inspired similar programmes in dozens of countries. This article offers a critical review of the conceptual foundations, historical roots, features, impact and limitations of PBF.

The article has six substantive sections. The first outlines the patterns of reproduction of poverty and inequality in Brazil and the social policies associated with import-substituting industrialisation (ISI). Their examination shows that Brazilian social policy has been driven by the imperatives of political stability and supporting the system of accumulation; that is, instead of being a lever for social integration and economic change, social policy has supported the reproduction of the prevailing patterns of social exclusion.

The second section reviews the implications for social policy of the 'twin' transitions from military dictatorship to democracy, and from ISI to neoliberalism. The consolidation of democracy and the 1988 'Citizen's Constitution' introduced a postwar European-style welfare state in Brazil, including the universal provision of public goods and services and the guarantee of a minimum standard of living. Paradoxically, Brazil adopted this social policy paradigm when it was being reversed elsewhere through the rise of neoliberalism, and its ambitious goals inevitably clashed with the macroeconomic limitations imposed by the neoliberal transition. The ensuing tensions led to the emergence of a wider citizenship, tempered by stringent financial limitations on the state. These contradictory principles were resolved through the targeting of social policy.

The third section reviews the principles of CCTs and their rise to global prominence in the 1990s, as the social policies typical of 'mature neoliberalism'. In this system of accumulation, the provision of public goods (education, transport, health, telecoms, electricity, water, sanitation and so on) is increasingly individualised, taking place through private markets supported, if necessary, by private loans, insurance and capital market instruments. In turn, the state provides token support to the destitute while bringing them to market as potential borrowers and residual buyers of commodities. Inevitably, CCTs are limited for cost, efficiency and equity reasons. Although they assist the target 
groups at the margin, CCTs offer only limited scope to address ingrained problems of poverty and exclusion. They curb citizens' rights through the imposition of commercial mediations and arbitrary conditions, address poverty and distribution only within narrow limits and subsidise low wages, helping to perpetuate poverty while overtly seeking to eliminate it.

The fourth and fifth sections review PBF and the controversies surrounding its effectiveness. The programme can be assessed only as part of the economic and social policies implemented in Brazil under mature neoliberalism (since 1999) and, in particular, in the administrations of Luís Inácio Lula da Silva and Dilma Rousseff (2003-present). Although significant improvements in poverty and inequality have taken place during this period, PBF has been both marginal and marked by the neoliberal conditions in which it has emerged. In reality, faster growth, improvements in labour markets and rising minimum wages have had a far more significant impact on poverty and inequality. However, the current modality of growth and distribution has become exhausted; Brazil's economic growth rate has slowed down, labour markets have weakened, and political constraints now prevent the aggressive use of fiscal policy to promote growth, macroeconomic stability and welfare improvements. This article suggests that further gains require a new economic and social policy model breaking with the limitations imposed by neoliberalism.

The conclusion summarises the evidence and outlines a pro-poor and democratic (universal) social policy alternative for Brazil.

\section{1 - Poverty, Inequality and Social Policy in Brazil}

The Brazilian economy has been driven by three systems of accumulation during the last century: primary export-led growth (until 1930), import-substituting industrialisation (ISI, 1930-80), and neoliberalism (since 1990). ${ }^{2}$ Social policy has supported their reproduction in multiple ways, including the regulation of demand, social stability, state legitimacy and the provision of skills, health, housing and mobility of labour. Because it has been invariably designed for these supporting roles, Brazilian social policy has never been a lever for social or economic change, nor has it driven the provision of basic goods and services. Instead, it has generally fostered a self-reinforcing dynamics of exclusion: the upper and middle classes have been served by a burgeoning private sector, while the poor have been precariously provided for by the public sector.

\footnotetext{
${ }^{2}$ For a detailed review, see Saad-Filho (2010).
} 
ISI was a strategy of conservative modernisation driven by manufacturing-led growth. Agriculture declined from $36 \%$ of GDP in 1910 to $10 \%$ in 1980, while manufacturing increased from 14 to $41 \%$ of GDP; average annual per capita income growth rates reached $8.7 \%$ between 1950 and $1980{ }^{3}$ Despite the rapid expansion of formal employment, income inequality tended to increase during this period, especially under the military dictatorship (1964-85). By the mid-1980s, the top $10 \%$ of earners captured half of national income, and the top $20 \%$ two-thirds. ${ }^{4}$

The contributory social security systems introduced by the populist dictatorship of Getúlio Vargas (1930-45), and expanded under the formally democratic Second Republic (1946-64) did not seek to eliminate poverty or reduce inequality. Instead, they provided income security to selected categories as part of a strategy of integration and subordination of formal sector (mostly urban, male and better-off) workers in manufacturing and public services. ${ }^{5}$ They were granted minimum wages, employment stability, maximum working hours, paid holidays, trade union representation, pensions and (within narrow limits of quality and quantity of provision) free health and education. These were provided by the state in association with business and (largely state-controlled) trade unions, which became distributional arms of the state. Most women and informal and rural sector workers were excluded. Thus, the state subsidised manufacturing through the socialisation of part of the cost of reproduction of its workforce, while simultaneously defusing dissent in urban areas.

The Second Republic collapsed in 1964, under the combined pressures of economic underperformance and spiralling tensions due to the emergence of movements contesting the existing patterns of inequality. The military dictatorship imposed a regressive industrialisation strategy based on the deepening of ISI, concentration of income and wealth and exclusion of civil society from the formulation of economic and social policy. The trade unions were brought under state control and political contestation was essentially outlawed. The regime offered token gestures to the poor, especially the extension of pensions and social security to some rural workers, and disability pensions and funeral assistance to the destitute. In contrast, large incentives were provided to private accumulation, including falling minimum wages and greater employment 'flexibility', plus tax breaks, consumer credit, subsidised health, pensions and housing finance and free tertiary education for the better-off. Consumption stagnated at the bottom and boomed at the top end of the distribution.

\footnotetext{
${ }^{3}$ Measured in PPP\$; source: Penn World Table, v.7.

${ }^{4}$ Pomar (2013, p.34).

${ }^{5}$ This 'workerist' welfare regime is examined by Seekings (2012).
} 
Rapid economic growth between the late 1960s and the mid-1970s led to the inclusion of a rising number of workers into the country's rudimentary welfare system. By the late 1970 s, $90 \%$ of the population received some social security coverage. However, the benefits were minimal and the infrastructure was either precarious or non-existent. Most of the benefits were captured by the formal sector workers, civil servants and military officers. ${ }^{6}$

The end of the post-war 'golden age', the oil shocks and the international debt crisis led to mounting balance of payments, fiscal and exchange rate problems in Brazil. They lowered investment and GDP growth rates, and sparked an inflationary process which peaked only in the mid-1990s. Unemployment and informal employment increased, and social demands spiralled out of control. It was increasingly accepted that political and economic changes had become imperative. The military regime collapsed in 1985 , when a mass democratic movement culminated in a negotiated transfer of power to a civilian President. One of the principal demands of that movement was the construction of a redistributive and universal welfare state. This demand was reflected in the 1988 'Citizen's Constitution', which capped the democratic transition.

Articles 194-203 of the Constitution created social rights based on principles of universality (rather than targeting), social security (as opposed to private insurance), and rights of citizenship (instead of charity or conditional access). The state was legally bound to provide social protection, pensions, housing and public education, and to introduce a national health system. Social gains included the reduction of the working week from 48 to 44 hours, employment security, protection against arbitrary dismissal, salary floors depending on skills and length of service, payments for overtime, minimum holidays, 120 days' maternity leave, 5 days' paternity leave, the right to strike, and recognition to independent trade unions. These rights and programmes were to be funded by specific taxes and contributions paid by employers and employees. ${ }^{7}$

The new Constitution introduced a welfare state in Brazil precisely when, elsewhere, it was being transformed by the neoliberal onslaught. Although Brazil was among the few countries where social spending increased in the 1990s, the expansion of public provision inevitably clashed against the political and budgetary limitations imposed by the transition to neoliberalism.

\footnotetext{
${ }^{6}$ See Coutinho (2013, pp.83-87), Fagnani (2005, pp.2, 41) and Mattei (2012).

${ }^{7}$ See Coutinho (2013, pp.89-91), Fagnani (2005, pp.xv-xvi, 219, 541-46), Leubolt (2013, p.72) and Trubek, Coutinho and Shapiro (2013).
} 


\section{2-Social Policy and the Neoliberal Transition}

The political transition to democracy in Brazil was followed by the economic transition from ISI to neoliberalism. Successive reforms since 1988 liberalised imports, finance and capital flows, privatised industry and infrastructure and increased labour 'flexibility', while institutionalising contractionary fiscal and monetary policies and promoting the integration of domestic with foreign capital. These reforms were justified by the presumed exhaustion of the developmental state and the imperative to contain inflation. Individual policy shifts morphed into a fully-fledged transition to neoliberalism under President Fernando Collor (1990-92), which was secured by the 1994 real inflation stabilisation plan under Presidents Itamar Franco (1992-1994) and Fernando Henrique Cardoso (1995-98, 1999-2002). ${ }^{8}$

The transition to neoliberalism transformed the country's social structure and patterns of employment. New production methods, labour-saving technologies, large-scale subcontracting, the simplification of managerial structures and the shift of the product mix towards lower value-added goods led to rapid productivity growth in the manufacturing sector in the 1990s; at the same time, manufacturing employment declined by $40 \%$, with the loss of 1.5 million jobs. Another half a million workers lost their jobs in the privatised industries. ${ }^{9}$

Low aggregate demand reduced economic growth and depressed investment in a vicious circle: per capita income rose only $2.7 \%$ per annum between 1981 and 2003, and Brazil fell from being the world's $8^{\text {th }}$ largest economy in 1980 , to $14^{\text {th }}$ place in 2000 . During the 1990 s, $54 \%$ of the jobs created were either informal or unwaged and, in 1997, the informal sector employed $25 \%$ of the urban workforce. Unemployment in the metropolitan areas increased from $8.7 \%$ in 1989 to $18.3 \%$ in 1998, and the average length of unemployment rose from 15 to 36 weeks. ${ }^{10}$ The cumulative result was the decline of the labour share in national income from $50 \%$ in 1980 , to $36 \%$ in the early 2000s. ${ }^{11}$ Poor economic performance was accompanied by a fiscal deterioration. Despite continuing austerity and an increase in taxation by 10 percentage points of GDP, the domestic public debt (DPD) rose from $33 \%$ of GDP in 1993 , to $55 \%$ in $2002 .^{12}$

\footnotetext{
${ }^{8}$ See Mollo and Saad-Filho (2006) and Saad-Filho (2007b).

${ }^{9}$ See Feijó and Carvalho (1998) and Pochmann (2006, p.137; 2011, p.16).

${ }^{10}$ See Antunes and Pochmann (2008, pp.5-6), Pochmann (2003, p.7), Pomar (2013, pp.41-5) and Santos (2001).

${ }^{11}$ Câmara and Vernengo (2007, p. 77) and Pochmann (2011, p.16).

${ }^{12}$ Pochmann (2011, p.16).
} 
The neoliberal transition expanded social needs because of the growth slowdown, higher unemployment and the informalisation of work; it simultaneously reduced the state's capacity to fulfil the Constitutional social rights because of financial limitations, the depletion of state administrative capacity and the spiralling burden of the domestic and external debts, which increased from 37 to $58 \%$ of the budget between 1995 and $1998 .^{13}$ The federal government created a misnomered 'Social Emergency Fund' (Fundo Social de Emergência, FSE) in 1994, which cut social spending by $20 \%$, reduced transfers to states and municipalities by $15 \%$ and raised federal taxes and contributions by 5\%. The government also diverted the Provisional Contribution on Financial Transactions (Contribuição Provisória sobre Movimentações Financeiras, CPMF), which should have funded the new National Health Service (Sistema Único de Saúde, SUS) to service the DPD; a similar fate befell the Contribution on Net Profits (Contribuição sobre o Lucro Líquido, CSLL) and the Contribution on Enterprise Revenue (Contribuição sobre o Faturamento das Empresas, Cofins), which should have funded social spending. Finally, severe funding constraints were imposed on states and municipalities, despite their Constitutional duty to provide an expanded set of welfare services. ${ }^{14}$

At the same time, the social chapter of the Constitution was criticised because universal rights were allegedly 'too expensive' and 'incompatible with fiscal and monetary stability'. Even if they were affordable, the benefits were alleged to be regressive because they were appropriated by corrupt politicians, lazy scoundrels and middle-class civilian public sector workers, at the expense of the education of children and the health of the poor. Heavy political and media pressure claimed that universal programmes were either unaffordable or undesirable, and that only the economically active poor and the 'deserving destitute' merited (limited) public support. This discourse validated government initiatives to reduce investment in housing, sanitation and public transport, postpone universal health, education and social security provision, prune workers' rights and pensions, dilute unemployment support and food assistance programmes and curtail land reform, while continuing to service the foreign debt and subsidising private capital through the rapid expansion of the DPD. ${ }^{15}$

In place of constitutionally mandated public services, the neoliberal state fostered the individualisation of welfare provision backed up by private loans and insurance, and supplemented by ad hoc, modest, targeted and ostensibly transitory relief programmes providing handouts to the

\footnotetext{
${ }^{13}$ Mattei (2012, p.157) and Sánchez-Ancochea and Mattei (2011, pp.302-03).

${ }^{14}$ See Fagnani (2005, p.440 et seq.).

${ }^{15}$ See Fagnani (2005, pp.547-55).
} 
desperately needy. As the emerging Brazilian welfare state morphed into a neoliberal 'minimal state', pauperism became the core of social policy in Brazil: ${ }^{16}$ the neoliberal state manages misery through the conditional apportionment of tax-funded alms to the deserving destitute. In doing this, the state assists the wretched while it subsidises the worst modalities of employment by 'conditionally' supplementing the lowest incomes. The transfers provided to large capital and the financial institutions were protected.

\section{3-Social Policy under Mature Neoliberalism: The Irresistible Rise of CCTs}

Conditional cash transfer programmes (CCTs) have proliferated since the mid-1990s, with Latin America at the forefront. CCTs are conditional safety nets comprising small monetary transfers to households that are either extremely poor or highly vulnerable to deprivation, especially those with children. Benefits are generally paid to mothers, both to empower women and because their behaviours are presumably more closely aligned with the intended use of the funds. The conditionalities were transposed from structural adjustment programmes to the level of households. They can be either light-touch (as with PBF) or intrusive and time-intensive (as with the Mexican Oportunidades programme). They are expected, first, to weed out 'undeserving' applicants; second, to reward behaviours matching the social optimum, including building up human capital, promoting growth and blocking the inter-generational transmission of poverty, and, third, to secure taxpayers' support through the reassurance that no one is given too much, too easily, or indefinitely. Noncompliance with the conditionalities could lead to the suspension of benefits, fines, or exclusion from the CCT. Within these parameters, CCTs are flexible. Assistance can include cash, food, housing, fee waivers, scholarships or employment, and conditionalities may include school attendance, preventative health care (especially participation in health workshops, vaccinations and check-ups for pregnant women and children) and community work, typically cleaning or rubbish clearance. $^{17}$

Advocates of CCTs expect them to reduce poverty both in the short and in the long run. Immediately, the transfers alleviate destitution and, in the longer term, the conditionalities strengthen the recipients' position in the labour market, eventually obviating the need for the programme. CCTs also boost the consumption of locally-produced goods without undercutting producers' prices, as food programmes often do, and they are cheap to run, as payments are low and

\footnotetext{
16 'Pauperist' welfare regimes are described by Seekings (2012).

${ }^{17}$ See Barrientos (2007, p.67), Hall (2008) and Molyneux (2007).
} 
targeting draws upon centralised data systems which accurately identify the beneficiaries, preventing multiple claims and limiting corruption. ${ }^{18}$ In sum, CCTs 'have spread because they work. They cut poverty. They improve income distribution. And they do so cheaply' ${ }^{19}$

CCTs have superseded fads previously sponsored by the World Bank, NGOs and other international organisations, including pension privatisation in the 1980s, and microfinance in the 1990s. They all seek to optimise the allocation of scarce resources, align incentives with the behavioural requirements of neoliberalism, and compensate the poor for the asymmetric impact of the 'reforms', especially higher unemployment and loss of property, income, marketable skills and access to public services. ${ }^{20}$

The leading role of Latin America in the diffusion of CCTs has been attributed to the coexistence of widespread poverty with plentiful resources, in contrast with poorer regions where large social programmes are impractical. The mainstream also claimed that, previously, social provision in Latin America was mostly captured by the middle classes, while the delivery of the remainder to the poor was mediated by patronage or corruption. In order to address these distortions, the World Bank proposed governance improvements and targeted programmes. ${ }^{21}$ Finally, the 'pink wave' administrations spreading since the early 2000s welcomed the opportunity to address the needs of the poor while avoiding conflicts with the rich. CCTs were introduced gradually: in most countries, targeted initiatives were initially aspects of universal programmes; they later became alternatives and, eventually, CCTs embodied the country's social policy.

CCTs are limited at six levels. First, they reflect the contradiction between the expansion of citizen's rights in a democracy, including the right to a minimum living standard, and the limitation of social provision under neoliberalism. CCTs accommodate these conflicting imperatives through the provision of limited assistance to selected groups: for those with very little, anything extra helps. In exchange for alms, the beneficiaries must fulfil duties springing from a combination of common sense, expert opinion and political expediency, which are imposed 'for their own good' (presumably, the poor are not just unlucky but also irrational, since they are disinclined to do what

\footnotetext{
${ }^{18}$ Seekings (2012), Molyneux (2007, p.69) and World Bank (2009, pp.8-11).

${ }^{19}$ The Economist (2010). Nancy Birdsall, president of the Center for Global Development, claimed that 'these programs are as close as you can come to a magic bullet in development' (Dugger 2004).

${ }^{20}$ See Fine and Saad-Filho (2014), Ghosh (2011), Hall (2008), Mattei (2012, p.169) and Seekings (2012, p.14).

${ }^{21}$ See World Bank (2000-01).
} 
is in their own interests). ${ }^{22}$ At best, CCTs belong to the paternalistic workfare tradition; at worst, they revive the Poor Law. Finally, it is paradoxical that the International Financial Institutions support targeting in social policy while rejecting it in industrial, financial and exchange rate policy because states are, presumably, too weak, ignorant or corrupt to direct resources to socially determined goals. Yet, they are expected to do this in social policy without fear of contradiction. ${ }^{23}$

Second, CCTs are designed to be cheap and unobjectionable. They are too small to support macroeconomic stabilisation and growth or to transform the life chances of the poor, boost their assets or improve their income-generating capacity - except, perhaps, in the long run, when the wage implications of marginally better schooling supposedly kick in (if a compatible job can be found). However, if mass poverty is primarily due to the lack of secure jobs, precarious livelihoods and adverse integration into the dominant economy, it can be soothed but not resolved by meagre benefactions (see section 5). Thus, CCTs are meant to be channelled into consumption; they include the poor by bringing them to the market as marginally less destitute buyers, and they are offered to the financial institutions as potential buyers of insurance policies or borrowers with a cash flow which can be used as collateral. While CCTs buttress financialisation and the privatisation of basic goods and services, they help turn the welfare state into a threadbare back-stop available only to the desperate.

Third, arguments for targeting claim that it focuses scarce resources upon the neediest and, therefore, delivers maximum benefit per unit of expenditure. Despite its intuitive appeal, this argument is potentially misleading at two levels:

(1) Targeted programmes are much more expensive to manage than universal programmes, because of the need to update the identification systems continuously, fraud and fraud avoidance, and resource transfer costs. The initial screening costs $0.4 \%$ to $29 \%$ of the programme costs, with $9 \%$ being a typical figure. In contrast, self-targeting programmes cost around $6 \%$. Once the poor have been identified, the other costs above become relevant, reaching around $30 \%$ of programme costs, in contrast with $15 \%$ for universal programmes (costs are lower in the advanced economies). ${ }^{24}$

(2) Targeting involves two types of errors: Type I (undercoverage, or unjustified exclusion of the poor) and Type II (leakage, or unwarranted inclusion of the non-poor). Given the budget, the

\footnotetext{
${ }^{22}$ See Standing (2011).

${ }^{23}$ Mkandawire (2005, pp.11-12).

${ }^{24}$ Dutrey (2007, pp.8-9), IDEAs (2011).
} 
minimisation of one error normally increases the likelihood of the other; conversely, more advanced identification tools can minimise both errors, but they tend to increase costs. ${ }^{25}$ Even the most successful CCTs include large errors: in an early study, $70 \%$ of the poor were excluded from Oportunidades, in Mexico, and 59\% from PBF. Conversely, 49\% of the beneficiaries of PBF and $36 \%$ of Oportunidades were found to be non-poor. Despite the significance of both types of error, most CCT evaluations consider only the beneficiaries, rather than all the poor. For example, typical rates of 32\% leakage and 50\% undercoverage imply that two-thirds of the resources reach the poor - but this 'efficiency' is partly due to the exclusion from the programme of half its potential beneficiaries. $^{26}$

Most programme evaluations focus on leakage only, that is, how much the target group has gained compared with the previous scheme, or with a universal alternative. A reference World Bank study of 122 targeted anti-poverty interventions in 48 countries claimed that targeting generally transfers $25 \%$ more to the poor than universal programmes. However, this study also shows that $25 \%$ of targeted programmes transfer fewer resources to the poor than the universal alternative, that the median targeting programme in sub-Saharan Africa transfers $8 \%$ less to the poor than a universal programme, and that the efficiency of targeting is positively correlated with per capita GDP, suggesting that targeting depends on institutional capacities that may be lacking in the poorer countries.

Fourth, targeting undermines social cohesion. It bypasses collective organisations with a stake in society (trade unions, community associations, and so on), validates politically-driven limitations on public provision and compels the poor to manage their own dispossession, while threatening to deprive them of their civic rights unless they meet extraneous conditions. ${ }^{27} \mathrm{CCT}$ s exclude the "nonpoor', defined arbitrarily by income thresholds often lower than the World Bank's US\$1.25/day poverty line. ${ }^{28}$ These thresholds exclude potential claimants both at the margin and inside it because of the costs and complexities of programme inclusion, and because poverty may be due to income volatility as much as by its baseline level, making it sometimes difficult to recognise. Those thresholds can also alienate the non-poor politically, since they fund CCTs through general taxation but cannot benefit from them. Their satisfaction with the use of funds may be tempered by

\footnotetext{
${ }^{25}$ For van Oorschot, "it is the "tragedy of selectivity" that trying to target welfare to the truly needy inherently means that a part of them will not be reached' (Mkandawire 2005, p.9).

${ }^{26}$ Dutrey (2007, pp.2-3), Mkandawire (2005, p.9).

${ }^{27}$ Freeland (2007, p.77).

${ }^{28}$ Lavinas (2013, p.23).
} 
aggravation towards the 'parasitical' destitute, however harsh may be the conditionalities. These constraints divide the poor and the poor from the non-poor, and hinder the achievement of the ultimate goals of social policy. ${ }^{29}$

Fifth, the conditionalities can be fulfilled only if the state makes services available; the state is also the prosecutor, judge and jury of the 'success' of the poor in satisfying the conditions imposed upon them. ${ }^{30}$ This programme structure can obscure state failure to provide basic services, while punishing the poor for not accessing facilities that realistically are unavailable to them. Experience shows that successful social policy depends on the combination of resource transfers and social provision, which can be achieved only with sufficient budgets. No amount of conditionality can improve this trade-off, except through large-scale programme exclusion.

Sixth, CCTs may not empower women. Women are the vessels through which the programmes reach their main targets, the children. ${ }^{31}$ While women's enhanced status may promote gender equality, it may also consolidate their caring role, as women are expected to fulfil governmentimposed conditionalities while continuing to service others in their household. In contrast, their partners' time and income are sheltered, and they are excused from the burden of childcare. Either outcome is possible: '[t]he only safe conclusion that can be drawn on the matter of whether stipends empower women on not, is that we do not know' ${ }^{32}$

Evaluations of the impact of CCTs have led to conflicting results. The conditionalities have often been correlated with marginal improvements in the target variables (school attendance, vaccinations, pre-natal care, and so on), especially in the poorest areas. ${ }^{33}$ In contrast, where basic services were already available (e.g., state schools in Argentina and Brazil), there is little scope for CCTs to increase child matriculation. ${ }^{34}$ Thus, the cheapness and residual nature of CCTs, which makes them popular, also leads to the rapid exhaustion of their potential achievements, while

\footnotetext{
${ }^{29}$ See Korpi and Palme (1998).

30 '[W]ithin countries, the areas typically inhabited by the most vulnerable groups are often those where health and education services are weakest, making them wholly unsuitable to this kind of approach [CCTs]. Similarly, it is typically the poorest and most vulnerable who will find it most costly to comply with any conditionalities, and are therefore the most likely to be deprived of benefits if they fail to do so - not the optimal model for a social protection programme' (Freeland 2007, p.77).

${ }^{31}$ The recipients of PBF and Oportunidades are, respectively, 92.4\% and 95.5\% female (Lavinas, Cobo and Veiga, 2012, p.33).

${ }^{32}$ Molyneux (2007, p.71); see also pp.70-72, Ghosh (2011, p.69), Lavinas (2013, p.28) and Quijano (2009).

${ }^{33}$ See Grosh (2011), World Bank (2009) and http://www.worldbank.org/en/topic/socialprotectionlabor

${ }^{34}$ Lavinas (2013, p.24); see also De Janvry and Sadoulet (2004, pp.2-3) and Freeland (2007).
} 
continuing gains require increasingly refined targeting and escalating penalties. The logical consequence is the incremental tailoring of conditionalities and the individualisation of social provision; that is, the destruction of collectivity in social policy. The removal of these limitations requires the elimination of the conditionalities and the universalisation of provision.

\section{4 - The Bolsa Família Programme}

The transition to neoliberalism in Brazil was completed in 1999, with the introduction of a rigid macroeconomic policy framework including inflation targeting, central bank independence, floating exchange rates, capital mobility and contractionary fiscal and monetary policies. These policies were imposed by the Cardoso administration, and they were maintained by Luís Inácio Lula da Silva (2003-06, 2007-10) and Dilma Rousseff (2011-present), despite a neo-developmentalist policy inflection in $2006 .{ }^{35}$ Brazilian social policies have been heavily conditioned by those macroeconomic policies.

CCTs became central to Brazilian social policy only gradually. In 1996, the Cardoso administration launched the Solidarity Community Programme (Programa Comunidade Solidária), including targeted policies to address acute deprivation. ${ }^{36}$ At the same time, local governments started experimenting with targeted transfer programmes. Basic income initiatives were pioneered in Campinas and Ribeirão Preto, and transfers to families with children, conditional on school attendance, were introduced in Brasília. They were copied elsewhere, although sometimes the technical and financial conditions were lacking and the programmes failed. ${ }^{37}$

In 2002 the federal government replaced the (universal) cooking gas subsidy with a cash transfer to 8.5 million poor families (Auxílio Gás, managed by the Ministry of Mines and Energy). The Bolsa Escola programme (managed by the Ministry of Education) funded 5.1 million poor families to send their children to school, and a food subsidy (Bolsa Alimentação, managed by the Ministry of Health), conditional on women's prenatal care and child health monitoring, vaccination and education, reached 900,000 families. ${ }^{38}$ Finally, PETI (Programa de Erradicação do Trabalho Infantil, managed by the Ministry of Labour) subsidised poor families to send their children to

\footnotetext{
${ }^{35}$ See Morais and Saad-Filho $(2011,2012)$.

${ }^{36}$ For a review, see Mattei (2012).

${ }^{37}$ See Fagnani (2005, p.554) and Mattei (2012, p.156).

${ }^{38}$ See Coutinho (2013, pp.94-95) and Leubold (2013, p.75).
} 
school instead of work. However, those programmes ware poorly co-ordinated (some households could claim all benefits, others were unable to claim anything), competition between providers, managerial difficulties across the federal, state and municipal levels, and funding limitations. ${ }^{39}$

In 2003, the Lula administration brought together the first three initiatives into the Fome Zero (Zero Hunger) programme, which also included a 'food card' (Cartão Alimentação) with which to purchase selected food items. Fome Zero ran into difficulties because its component parts operated independently and had distinct selection methods, reporting procedures and banking arrangements; their databases were incomplete, leading to targeting errors, duplication and high administrative costs, and there were allegations of manipulation in the selection of beneficiaries. In October 2003 these four programmes were merged under the label Bolsa Família. PETI was included in 2006. The conditionalities were amalgamated, and the benefits raised. The household was defined as the operational unit of the programme, and the female head was chosen as its main recipient. In January 2004, the Ministry of Social Welfare merged with the Ministry of Food Security and Fight against Hunger to form the Ministry of Social Development and Fight against Hunger (MDS), which manages $\mathrm{PBF}^{40}$

PBF provides benefits to extremely poor families (per capita monthly income below $\mathrm{R} \$ 70$, or US\$30 in February 2014) and to poor families (per capita monthly income between $\mathrm{R} \$ 70$ and $\mathrm{R} \$ 140$ ). The programme comprises a basic (unconditional) benefit of $\mathrm{R} \$ 70$, paid only to extremely poor families, and two variable benefits. The first, of $\mathrm{R} \$ 32$, is paid to families with children aged up to 15 , up to a maximum of three children. The second, of $\mathrm{R} \$ 38$, is paid for children ages 16-17, up to a maximum of two children. Thus, PBF pays between R $\$ 70$ and R $\$ 242$ (US\$30-US\$100) per family, with the average benefit being $\mathrm{R} \$ 150$ (7\% of Brazil's per capita income). ${ }^{41}$

Benefits are paid monthly and accessed through a card issued by Caixa Econômica Federal, a large state-owned bank. The variable benefits are conditional on school attendance (minimum $87 \%$ for children aged 6-15 and 75\% for those aged 16-17); vaccinations and medical follow-ups on children aged up to 7, check-ups and prenatal care for women aged 14-44, and checks on lactating mothers and their babies. The first violation of a conditionality brings a warning; after the second the benefit is blocked for one month (it may be repaid when the conditions are fulfilled); the third and fourth violations lead to the suspension of the benefit for two months (without repayment); after the fifth

\footnotetext{
${ }^{39}$ Sánchez-Ancochea and Mattei (2011, p.302).

${ }^{40}$ Hall (2008, pp.803-05); see also Marques (2013).

${ }^{41}$ http://www.mds.gov.br/bolsafamilia/beneficios
} 
the benefit is cancelled. No penalty should be imposed for non-compliance due to force majeure, e.g., lack of services, illness of the child, or illness or death in the family. Negligence, begging, child labour, violence and sexual abuse are subject to sanction. ${ }^{42}$

In contrast with public health and education, unemployment benefits, old age and disability pensions (Benefício de Prestação Continuada, BPC), ${ }^{43}$ and basic social security (Regime Geral da Previdência Social), which are Constitutional entitlements, $\mathrm{PBF}$ is a government programme introduced by Medida Provisória 132, converted into Law 10836. Thus, PBF can be modified and even discontinued by Presidential fiat; the law mandates a review of the beneficiaries every two years, and it limits the number of beneficiaries according to the PBF budget, which makes it vulnerable to the vagaries of macroeconomic performance and political bargaining. Despite these limitations, the unconditional element of PBF implicitly recognises that everyone is entitled to a minimum guaranteed income, which could provide a platform for a universal basic income programme. $^{44}$

The database supporting the PBF (Cadastro Único para Programas Sociais, CUPS) is centralised at MDS, and it currently includes 23 million low income families (up from 14 million in 2007). ${ }^{45}$ CUPS has allegedly increased the visibility of the poor and made it easier to reach them. PBF is not only the largest but also, allegedly, the best targeted CCT in Latin America, with $73 \%$ of benefits reaching the poorest $20 \%$ of the population, and $94 \%$ the bottom two quintiles. ${ }^{46}$ Around $50 \%$ of beneficiaries live in the Northeast of Brazil, the poorest region, and $25 \%$ in the Southeast, the most populous region. In 2013, PBF reached 14 million families including, for the first time, the homeless, inhabitants of isolated hamlets and members of indigenous groups. PBF currently benefits 50 million people ( $25 \%$ of the country's population), and over one-third of primary school children (see Table 1).

\section{$<$ TABLE 1 ABOUT HERE $>$}

\footnotetext{
${ }^{42}$ Coutinho (2013, pp.109-11). 2012 and Leubold 2013).

${ }^{44}$ Marques (2013, pp.308, 312); see also Coutinho (2013, p.102) and Mattei (2012, p.161).

${ }^{45}$ http://www.mds.gov.br/bolsafamilia/cadastrounico.

${ }^{46}$ Hall (2008, p.807); see also Coutinho (2013, p.76).
}

${ }^{43} \mathrm{BPC}$ is a non-contributory transfer awarded to those aged over 65 or unable to work or lead an independent life, and whose per capita household income is below $25 \%$ of the minimum wage. BPC transfers are Constitutionally set at one minimum wage, which is much higher than PBF payments. Consequently, BPC (including Lifelong Monthly Income, Renda Mensal Vitalícia, RMV) costs more than PBF, even though it has only a fraction of the beneficiaries (see IPEA 
Despite its low cost, under $0.5 \%$ of GDP ( $0.8 \%$ of household income), it has been claimed that PBF explains one-third of the decline in extreme poverty and $16 \%$ of the decline in poverty between 1999 and 2009, and 16\% of the reduction of income inequality between 1999 and 2009 (see section 5). ${ }^{47}$ Government studies claim that PBF has raised school attendance by 4.4 percentage points and improved progression by 6.0 percentage points, supported child nutrition and vaccination, and that PBF mothers have more prenatal appointments than non-recipient mothers. ${ }^{48}$ They also claim that PBF has empowered women not only through their purchasing power, but also because registration for PBF has led many to acquire a birth certificate and an identity card, which are essential for citizenship. ${ }^{49}$ Finally, they argue that PBF has driven economic growth in the poorest municipalities.

There is no evidence that the transfers have displaced paid work or encouraged 'idleness': threequarters of recipients are economically active, about the same proportion as in the wider population, and the vast majority of recipients declares not having rejected paid employment in order to remain in PBF. ${ }^{50}$ However, unemployment and informal employment remain higher amongst the recipients of cash transfers, especially PBF. ${ }^{51}$ They are, literally, working poor, and unemployment remains their main source of vulnerability.

Unsurprisingly, PBF has gained massive support among the poor. ${ }^{52}$ The votes received by Lula and Dilma in the presidential elections in 2006 and 2010 were strongly correlated with the number of PBF beneficiaries in each municipality ${ }^{53}$ and the popularity of both Presidents among the poor has remained extremely high regardless of the adverse media pressure.

Yet, several studies have questioned the impact of PBF. ${ }^{54}$ They claim that PBF has benefitted primarily the extremely poor living in rural areas, even though Brazil's population is $85 \%$ urban. In

\footnotetext{
${ }^{47}$ Marques (2013, p.304) and Soares et al (2010). For alternative estimates, see Mattei (2012, pp.166-68).

${ }^{48}$ IPEA (2012, pp.16, 21).

${ }^{49}$ Hall (2008, p.810).

${ }^{50}$ Lavinas, Cobo and Veiga (2012, pp.37-38).

${ }^{51}$ Hall (2008, p.815); see also Castro and Modesto (2010, p.21) and the detailed study by Leichsenring (2010).

52 "Those who have recently begun getting larger payments have no doubt about whom to credit: "First, I thank God," said Maria Andrade, an illiterate woman who for the first time was able to buy flip-flops for her barefoot children. "Second, I thank President Lula"' (Dugger 2004).

${ }^{53}$ See Marques et al (2009).

${ }^{54}$ See, for example, Hall (2008), Marques (2013, p.303), Mattei (2012) and Sánchez-Ancochea and Mattei (2011).
} 
the cities, PBF has brought negligible gains in education, health, vaccination and nutrition; it is also too small to have a macroeconomic and anticyclical impact. Some of these limitations have been attributed to the small size and self-limiting nature of PBF, and others to difficulties accessing public services or their low quality. PBF has also been unable to include around 2-3 million potentially eligible families (6-8 million people). This may be due to their failure to register (the extremely poor may be unable or unwilling to submit the required paperwork), fear of stigmatisation or exclusion due to income volatility, given the programme's low income thresholds. ${ }^{55}$ Moreover, PBF benefits are not linked to inflation, and they have declined in real terms by $25 \%$ since 2009 . Finally, the conditionalities have made it difficult for the beneficiaries especially women - to find and maintain stable jobs, which is especially perverse given the emancipatory goals of the programme. ${ }^{56}$

These disputes serve to illustrate the small impact of PBF, compared to the (large and undisputed) welfare effect of improvements in the Brazilian labour markets during the 2000s (see section 5). Given these limitations, the contribution of PBF to further improvements in poverty and distribution is likely to decline, in comparison with economic growth, changes in the labour markets and the expansion of citizenship.

\section{5 - Growth, Distribution and Social Policy under Lula and Dilma}

The pattern of growth under Lula and Dilma was unquestionably pro-poor, and it reduced poverty and inequality across a broad spectrum of measures. ${ }^{57}$

Faster growth led to the creation of 21 million jobs in the 2000s, in contrast with 11 million during the 1990s. Around $80 \%$ of those jobs were in the formal sector, which expanded from 45 to $51 \%$ of the workforce. ${ }^{58}$ Approximately $90 \%$ of these jobs paid less than 1.5 minimum wages (in contrast with $51 \%$ of those created in the 1990s). Unemployment declined especially among the lower income brackets; in 2014, it fell below $6 \%$ for the first time in decades.

\footnotetext{
55 See Lavinas (2013, p.28), Mattei (2012, p.170) and Sánchez-Ancochea and Mattei (2011, p.305).

${ }^{56}$ For a detailed study, see Lavinas, Cobo and Veiga (2012, p.52).

${ }^{57}$ Saad-Filho (2007a) and Saad-Filho and Morais (2014).

${ }^{58}$ See Pomar (2013, p.42) and www.ibge.gov.br.
} 
After a decade-long stagnation, average real wages grew 4.2\% per year between 2003 and 2012, while real per capita household income increased $4.6 \%$ per year. The real minimum wage rose $72 \%$ between 2005 and 2012, while real GDP per capita increased by 30\%. Rising minimum wages lifted the floor of the labour market and triggered simultaneous increases in federal transfers and pensions. Thus, the income of the poorest $10 \%$ rose $6.3 \%$ annually between 2001 and 2011, in contrast with $1.4 \%$ per annum for the richest $10 \% .{ }^{59}$ These gains have been concentrated in the poorer regions, with real wages in the Northeast rising at twice the national rate. Incomes rose faster in the poorer periphery than in the wealthier centre of São Paulo, and more in rural than in urban areas. Female income rose by $38 \%$ against $16 \%$ for men $(60 \%$ of the jobs created in the 2000 s employed women), and the income of blacks rose $43 \%$ against $20 \%$ for whites. ${ }^{60}$

The country had 60 million poor people in 1993 (41\% of the population) and the same in 2003 $(35 \%) .{ }^{61}$ Poverty fell below 30 million (15\% of the population) in 2012 . The extremely poor reached 29 million in 1993 (19\% of the population), and 26 million in 2003 (15\%), but fell under 10 million in 2012 (5\%). The proportion of poor households fell from 35\% in 1993 to $28 \%$ in 2003, and $12 \%$ in 2012 (see Table 2).

\section{$<$ TABLE 2 ABOUT HERE $>$}

The poverty figures include earned income, pensions and transfers (including PBF). If only earned income is taken into account, $48 \%$ of the population would be poor in $2001 .{ }^{62}$ Pensions lifted $11 \%$ above the threshold (18 million people), while the embryonic cash transfer programmes lifted another $1 \%$. By 2011, higher employment, wages and minimum wages had reduced poverty to $26 \%$. Pensions reduced poverty by another $11 \%$, and cash transfers lifted from poverty another $4 \%$ of the population. Pensions and transfers had a similar impact on extreme poverty, but wage growth had a smaller impact because of the greater precarity and lower wages of the extremely poor. Extreme poverty fell $39 \%$, from 28 to $17 \%$ of the population, in contrast with the decline of $46 \%$ in poverty.

\footnotetext{
${ }^{59}$ Paes de Barros, Grosner and Mascarenhas (2012, p.15).

${ }^{60}$ See Bastos (2012), Pochmann (2010, pp.640, 648; 2011, p.38; 2012, p.32) and Tible (2013, p.68).

${ }^{61}$ Number of people in households with per capita income below the poverty line, which is defined as twice the line of extreme poverty. The latter is determined by the cost of a food basket including the minimum calories recommended by FAO and WHO (www.ipeadata.gov.br).

${ }^{62}$ This paragraph draws on Lavinas (2012, pp.18-21; 2013, pp.29-31).
} 
Federal social spending increased by $172 \%$ in real terms (125\% per capita) between 1995 and 2010, rising from $11.0 \%$ of GDP to $15.5 \%$ (16.2\% in 2011). Their growth was especially rapid after 2003. Higher spending allowed existing programmes to expand, new ones to be created, including PBF, higher payments (two-thirds of which are fixed at one minimum wage), and the expansion of beneficiaries from 14.5 million to 24.4 million (77\% of $60+$ year-olds receive benefits). However, most informal workers remain excluded from social security, having no maternity pay, illness cover or pensions in case of retirement, disability or death. ${ }^{63}$

During the above period, $90 \%$ of social spending was absorbed by social security, social assistance (including PBF and BPC), health, education and pensions and benefits of state employees. The remaining $10 \%$ went to labour protection, food and nutrition, culture, agrarian development, housing and urban development and sanitation. The shares of direct transfers and state provision of public services within social spending have remained constant, at around $70 \%$ and $30 \%$, respectively (see Table 3). Since total spending nearly tripled, direct transfers rose much faster than public provision, by $\mathrm{R} \$ 285$ billion against $\mathrm{R} \$ 188$ billion (in constant December 2011 values), and from $7.6 \%$ to $10.8 \%$ of GDP, against $3.6 \%$ to $4.7 \%$.

\section{$<$ TABLE 3 ABOUT HERE $>$}

The outcome has been a significant distributional improvement in one of the most unequal countries in the world. The Gini coefficient fell from 0.60 at the turn of the century to 0.53 in 2012, while the income ratio between the top $10 \%$ and the bottom $40 \%$ fell from 23 to $15 .^{64}$

Higher wages, distributional improvements, the expansion of social programmes and the expansion of credit have benefitted tens of millions of people. For the first time, many can visit shopping centres, fly across the country and buy a small car. The automobiles in circulation rose from 42 million in 2005 to 81 million in 2013, while the number of passengers in Brazil's 63 largest airports rose from 96 million to 135 million. ${ }^{65}$ These consumption patterns can be criticised because they are socially undesirable, macroeconomically destabilising, environmentally unsustainable or because they support large capital, but they express some of the wants of the poor. However, rising incomes at the bottom of the pyramid have not been accompanied by improvements in infrastructure, leading

\footnotetext{
${ }^{63}$ Castro et al (2012, pp.14, 29), Chaves and Ribeiro (2012, p.11).

${ }^{64}$ www.ipeadata.gov.br.

${ }^{65}$ http://www.denatran.gov.br/frota.htm; http://www.infraero.gov.br/index.php/estatistica-dos-aeroportos.html
} 
to a generalised perception of deterioration in the quality of urban life. ${ }^{66}$ The ensuing tensions may have contributed to the social explosion in June-July 2013, and they might influence the outcome of the 2014 elections.

The Brazilian economy has been slowing down since 2010. GDP growth rates have declined from an admittedly exceptional $7.5 \%$ in 2010 to $2 \%$ per annum, resuming their trajectory under Cardoso (although the distributional impact of growth remains much better). Employment growth has tapered off, the rise of the minimum wage has slowed down, the formalisation of the workforce has paused, and the transfer programmes are limited by the fiscal deterioration. Subcontracting continues to increase, and these workers earn 40-60\% less than their peers in formal employment. This might help to explain the high proportion of low-paid jobs created in the 2000s, and the slow recovery of the wage share of income, which rose only from $38 \%$ in 2000 to less than $50 \%$ today (the same level of 30 years ago, under ISI and the military dictatorship). ${ }^{67}$ Further gains in poverty and distribution will require a change of approach.

The improvements in poverty and distribution during the last decade have not been driven primarily by changes in social policy or provision, but by labour markets, especially the creation of large numbers of low-paid jobs, the formalisation of employment and the increase of the minimum wage. The transfer programmes were responsible for only $34 \%$ of the decline of the Gini coefficient in 2001-08, while labour income was responsible for $65 \%{ }^{68}$ There is no question that the main drivers of poverty and exclusion in Brazil are the lack of secure and well-paid employment and the insufficient provision of public services. In order to break these structures of reproduction of poverty, government policy should focus on labour markets and service provision. These can be supported, but not replaced, by the expansion of social transfers.

\section{Conclusion}

This article has examined PBF from a critical political economy perspective. It departs from a review of poverty, distribution and social policy in Brazil, showing that they are determined by the

\footnotetext{
${ }^{66}$ Lula famously claimed that much has changed in the homes of the poor in terms of access to consumer goods but, once they step outside, they find that nothing has changed in terms of public services; see http://osamigosdoPresidentelula.blogspot.co.uk/2013/09/entrevista-de-lula-eu-quero-ser.html and Saad-Filho (2013, p.668).

${ }^{67}$ Pomar (2013, p.42); see also Bastos (2012, pp.29-31).

${ }^{68}$ Hall (2008, pp.812, 815), Mattei (2012, pp.167-68).
} 
asymmetries constituting the dominant system of accumulation. The cases of ISI and neoliberalism are examined in detail.

While recognising the positive impact of PBF for the destitute, the article has highlighted two of its limitations. First, PBF contravenes the universal principles in the Constitution by focusing on the redistribution of tax-funded alms to the desperately poor, in order to discipline them through conditionalities, compel them to manage their destitution, and subsidise low wages. Only in the age of neoliberalism would such a limited programme be so sorely needed, and receive universal applause. Second, PBF is too small to eliminate even extreme poverty or block the reproduction of inequality; it is also divisive and non-transformative. Thus, it is fundamentally conservative.

Despite these limitations, PBF implicitly recognises that everyone is entitled to a minimum standard of living guaranteed by the state. This offers an avenue to improve social provision through the increase in the value of benefits, their universalisation and the removal of conditionalities: minimum income guarantees are 'desirable in themselves and constitute requirements for any civilised society'; ${ }^{69}$ they also help to expand and stabilise aggregate demand, and promote health, education and public security. However, there is only limited scope for these mutually-reinforcing developments. Successive federal administrations have maintained the 'mature' neoliberal policies introduced in 1999, albeit with a neo-developmental inflection in 2006. Their limitations have become clear as the burst of growth in the 2000s has evaporated because of fiscal, financial, inflation, balance of payments and exchange rate constraints, curtailing the government's ability to expand social provision.

A more ambitious social policy agenda must recognise the economic and social policy achievements under Lula and Dilma; it should also admit that these administrations have not improved enough the condition of the poor, especially in urban areas. Further advances in social provision, infrastructure, growth, poverty and distribution require not only technocratic solutions with a progressive character, but the integration of the country's macroeconomic and social policies and the transformation of the processes of income generation and social reproduction: that is, a shift in the system of accumulation including a rupture with neoliberalism.

This is essential because poverty cannot be eliminated, or inequality reduced significantly, by social policy: the resources available for distribution are determined by macroeconomic outcomes, and the

${ }^{69}$ Ghosh (2011, p.68); see also Coleman (2003). 
impact of earned income on poverty and inequality dwarfs the effect of transfers. International experience shows that the integration of universal protection with a pro-poor development strategy offers the most effective arrangement to neutralise market-generated poverty and inequality, promote equity, and translate expanding production capabilities into poverty reduction and greater equity. ${ }^{70}$ This strategy hinges on the expansion of social protection primarily through decommodification, in order to shelter the poor from the vagaries of market provision. Decommodification and the universalisation of provision also build coalitions among the poor and between them and the middle class, instead of dividing them under CCTs. Finally, they include the poor as a resource for development, instead of treating them as a drag to be addressed by conditional transfers. ${ }^{71}$

In contrast with this transformative strategy, mainstream responses deploy CCTs to moderate the most galling inequities and the most destabilising implications of neoliberalism. This is intrinsically limited. It does not address the causes of poverty, which are due to the lack of assets of the poor which, in turn, is due to the concentration of ownership elsewhere. The poor also suffer disproportionately from vulnerability in their livelihoods, including low pay, precarious employment, lack of land and dependence on fragile ecosystems. Consequently, addressing poverty requires changing the distribution of assets, access to stable and remunerative employment and reduced vulnerability to shocks. Instead of tackling these fundamental problems, social policy under neoliberalism is merely a tool of poverty management: a palliative addressing only the most urgent symptoms of poverty and inequality while subsidising their reproduction. ${ }^{72}$ Brazil's recent achievements provide an opportunity to build a more equal future. It should be seized.

\footnotetext{
${ }^{70}$ Pro-poor development strategies are outlined in Dagdeviren, van der Hoeven and Weeks (2002), Saad-Filho (2007a, 2011) and UNRISD (2010). Compatible social policies are examined by Korpi and Palme (1998) and Mkandawire (2005).

${ }^{71}$ Dutrey (2007, p.16).

${ }^{72}$ Ghosh (2011, p.68).
} 


\section{$\underline{\text { References }}$}

Antunes, R. and Pochmann, M. (2008) 'Dimensões do Desemprego e da Pobreza no Brasil', Revista Interfacehs, 3 (2), pp.1-10.

Barrientos, A. (2007) 'Understanding Conditions in Income Transfer Programmes: A Brief(est) Note', IDS Bulletin 38 (3), pp.66-68.

Bastos, E.K.X. (2012) Distribuição Funcional da Renda no Brasil: Estimativas Anuais e Construção de Uma Série Trimestral, Texto para Discussão IPEA, No. 1702, Brasília: IPEA.

Câmara Neto, A.F. and Vernengo, M. (2007) 'Lula's Social Policies: New Wine in Old Bottles?', in: P. Arestis and A. Saad-Filho (eds.) Political Economy of Brazil. London: Palgrave.

Castro, J.A. and Modesto, L. (eds.) (2010) Bolsa Família 2003-2010: Avanços e Desafios, Vol.1. Brasília: IPEA.

Castro, J.A., Ribeiro, J.A.C., Chaves, J.V. and Duarte, B.C. (2012) 'Gasto Social Federal: Prioridade Macroeconômica no Período 1995-2010', IPEA Nota Técnica no.9.

Chaves, J.V. and Ribeiro, J.A.C. (2012) 'Gasto Social Federal: Uma Análise da Execução Orçamentária de 2011', IPEA Nota Técnica no.13.

Coleman, N. (2003) 'Current Debates around BIG: The Political and Socio-economic Context', in G. Standing and M. Samson (eds.) A Basic Income Grant for South Africa. Cape Town: University of Cape Town Press.

Coutinho, D.R. (2013) 'Decentralization and Coordination in Social Law and Policy', in: D.M. Trubek, H. Alviar Garcia, D.R. Coutinho and A. Santos (eds.) Law and the New Developmental State. Cambridge: Cambridge University Press.

Dagdeviren, H., van der Hoeven, R. and Weeks, J. (2002) 'Poverty Reduction with Growth and Redistribution', Development and Change, 33, pp. 383-413.

de Janvry, A. and Sadoulet, E. (2004) Conditional Cash Transfer Programs: Are They Really Magic Bullets?, www.ifpri.org/sites/default/files/publications/beijingbrief_adato.pdf (accessed 28 February 2014).

Dugger, C.W. (2004) To Help Poor Be Pupils, Not Wage Earners, Brazil Pays Parents, http://www.nytimes.com/2004/01/03/world/to-help-poor-be-pupils-not-wage-earners-brazil-pays-parents.html

Dutrey, A.P. (2007) 'Successful Targeting? Reporting Efficiency and Costs in Targeted Poverty Alleviation Programmes’, UNRISD Social Policy and Development Programme Paper 35. Geneva, UNRISD.

Fagnani, E. (2005) Política Social no Brasil (1964-2002): Entre a Cidadania e a Caridade. PhD thesis, UNICAMP.

Feijó, C.A. and Carvalho, P.G.M. (1998). Structural Changes in the Brazilian Economy: An Analysis of the Evolution of Industrial Productivity in the 1990s, available at: http://isi.cbs.nl/iamamember/CD5-

Mexico1998/document/CON_PA 1/Cp10apar.doc (accessed 15 August 2013).

Fine, B. and Saad-Filho, A. (2014) 'Politics of Neoliberal Development: Washington Consensus and Post-Washington Consensus', in H. Weber (ed.) The Politics of Development: A Survey, London: Routledge.

Freeland, N. (2007) 'Superfluous, Pernicious, Atrocious and Abominable? The Case Against Conditional Cash Transfers', IDS Bulletin 38 (3), pp.75-78.

Ghosh, J. (2011) Cash Transfers as the Silver Bullet for Poverty Reduction: A Sceptical Note,

http://www.epw.in/specials/cash-transfers-silver-bullet-poverty-reduction-sceptical-note.html (accessed 28 February 2014).

Grosh, M. (2011) CCT's: The Second Generation of Evaluations, http://siteresources.worldbank.org/SOCIALPROTECTION/Resources/280558-1138289492561/21584341319815902013/Keith_MargaretGrosh.pdf (accessed 25 January 2014).

Hall, A. (2008) 'Brazil’s Bolsa Família: A Double-Edged Sword?' Development and Change 39(5), pp.799-822.

IDEAs (2011) Cash Transfers as a Strategy for Poverty Reduction: A Critical Assessment, http://www.networkideas.org/briefs/dec2011/pb29_Cash_Transfers.htm (accessed 28 February 2014).

IPEA (2012) A Dinâmica Recente das Transferências Públicas de Assistência e Previdência Social, http://www.ipea.gov.br/portal/images/stories/PDFs/comunicado/120308_comunicadoipea138.pdf (accessed 28 January 2014).

Korpi, W. And Palme, J. (1998) 'The Paradox of Redistribution and Strategies of Equality' American Sociological Review 63 (5), pp.661-687. 
Lavinas, L. (2012) Medindo o Grau de Aversão à Desigualdade da População Brasileira Através dos Resultados do Bolsa-Família, Relatório Final, Convenio FINEP 01.06.1064.00.

Lavinas, L. (2013) ' $21^{\text {st }}$ Century Welfare', New Left Review 84, pp.5-40.

Lavinas, L., Cobo, B. and Veiga, A. (2012) 'Bolsa Família: Impacto das Transferências de Renda sobre a Autonomia das Mulheres Pobres e as Relações de Gênero', Revista Latinoamericana de Población 6 (10), pp.31-56.

Leichsenring, A.R. (2010) 'Precariedade Laboral e o Programa Bolsa Família', in J.A. Castro and L. Modesto (eds.) Bolsa Família 2003-2010: Avanços e Desafios, Vol.1. Brasília: IPEA.

Leubolt, B. (2013) 'Institutions, Discourse and Welfare: Brazil as a Distributional Regime', Global Social Policy 13 (1), pp.66-83

Marques, R.M. (2013) 'Políticas de Transferência de Renda no Brasil e na Argentina', Revista de Economia Política, 33 (2), pp. 298-314.

Marques, R.M., Leite, M.G., Mendes, A. and Ferreira, M.R.J. (2009) 'Discutindo o Papel do Programa Bolsa Família na Decisão das Eleições Presidenciais Brasileiras de 2006', Revista de Economia Política, 29 (1), pp.114-132

Mattei, L. (2012) 'Políticas Públicas de Combate à Pobreza no Brasil: O Caso do Programa Bolsa Família', Revista da Sociedade Brasileira de Economia Política, 33, pp.147-176.

Mollo, M.L.R. and Saad-Filho, A. (2006) 'Neoliberal Economic Policies in Brazil (1994-2005): Cardoso, Lula and the Need for a Democratic Alternative', New Political Economy 11 (1), pp.98-123.

Molyneux, M. (2007) 'Two Cheers for CCTs', IDS Bulletin 38 (3), pp.69-74

Morais, L. and Saad-Filho, A. (2011) ‘Brazil beyond Lula: Forging Ahead or Pausing for Breath?', Latin American Perspectives, 38 (2), pp.31-44.

Morais, L. and Saad-Filho, A. (2012) 'Neo-Developmentalism and the Challenges of Economic Policy-Making under Dilma Rousseff', Critical Sociology 38 (6), pp.789-798.

Paes de Barros, R., Grosner, D. and Mascarenhas, A. (2012) Vozes da Classe Média: Caderno 2 - Desigualdade, Heterogeneidade e Diversidade. Brasília: Presidência da República.

Pochmann, M. (2003) 'Sobre a Nova Condição de Agregado Social no Brasil', Revista Paranaense de Desenvolvimento 105, pp.5-23.

Pochmann, M. (2006) 'Mercado Geral de Trabalho: O Que Há de Novo no Brasil?', Parcerias Estratégicas 22, pp.121144.

Pochmann, M. (2010) ‘Estrutura Social no Brasil: Mudanças Recentes’, Serviço Social \& Sociedade, 104, pp. 637-649.

Pochmann, M. (2011) 'Políticas Sociais e Padrão de Mudanças no Brasil Durante o Governo Lula', SER Social 13 (28), pp. 12-40.

Pomar, W. (2013) 'Debatendo Classes e Luta de Classes no Brasil', in Classes Sociais no Brasil de Hoje, available in http://novo.fpabramo.org.br/sites/default/files/ed01-fpa-discute.pdf (accessed 28 January 2014).

Quijano, M.A.F (2009) 'Social Policy for Poor Rural People in Colombia: Reinforcing Traditional Gender Roles and Identities?', Social Policy \& Administration 43 (4), pp. 397-408

Saad-Filho, A. (2007a) 'There is Life beyond the Washington Consensus: An Introduction to Pro-Poor Macroeconomic Policies', Review of Political Economy 19 (4), pp.513-537.

Saad-Filho, A. (2007b) 'Neoliberalism, Democracy and Economic Policy in Brazil', in: P. Arestis and A. Saad-Filho (eds.) Political Economy of Brazil. London: Palgrave.

Saad-Filho, A. (2010) 'Neoliberalism, Democracy and Development Policy in Brazil', Development and Society 39 (1), pp.1-28.

Saad-Filho, A. (2011) 'Growth, Poverty and Inequality: Policies and Debates from the (Post-)Washington Consensus to Inclusive Growth', Indian Journal of Human Development, 5 (2), pp.321-344.

Saad-Filho, A. (2013) 'Mass Protests under “Left Neoliberalism”: Brazil, June-July 2013', Critical Sociology 39 (5), pp.657-669.

Saad-Filho, A. and Morais, L. (2014) 'Mass Protests: Brazilian Spring or Brazilian Malaise?', in L. Panitch, G. Albo and V. Chibber (eds.), Socialist Register, London: Merlin Press, pp.227-246.

Sánchez-Ancochea, D. and Mattei, L. (2011) 'Bolsa Família, Poverty and Inequality: Political and Economic Effects in the Short and Long-Run’ Global Social Policy 11(2-3), pp.299-318 
Santos (2001) 'Mudanças na Estrutura de Posições e Segmentos de Classe no Brasil', Dados 44 (1), available (accessed 15 August 2013) at: http://www.scielo.br/scielo.php?script=sci_arttext\&pid=S0011-52582001000100005

Seekings, J. (2012) 'Pathways to Redistribution: The Emerging Politics of Social Assistance across the Global South"', Journal für Entwicklungspolitik 28 (1), pp.14-34.

Seekings, J. (2012) 'Pathways to Redistribution: The Emerging Politics of Social Assistance across the Global South', Journal für Entwicklungspolitik 28 (1), pp.14-34.

Soares, S., Souza, P., Osório, R. and Silveira, F.G. (2010) 'Os Impactos do Benefício do Programa Bolsa Família sobre a Desigualdade e a Pobreza, in J.A. Castro and L. Modesto (eds.) Bolsa Família 2003-2010: Avanços e Desafios, Vol.1. Brasília: IPEA.

Standing, G. (2011) 'Behavioural Conditionality: Why the Nudges Must Be Stopped', Journal of Poverty and Social Justice 19 (1), pp.27-38.

Thandika Mkandawire. T. (2005) 'Targeting and Universalism in Poverty Reduction', UNRISD Social Policy and Development Programme Paper 23. Geneva, UNRISD.

The Economist (2010) Give the Poor Money: Conditional-Cash Transfers Are Good; They Could be Even Better, 29 July, http://www.economist.com/node/16693323

Tible, J. (2013) 'O Fenômeno Político do Lulismo e a Construção de Uma Nova Classe Social', in Classes Sociais no Brasil de Hoje, available at http://novo.fpabramo.org.br (accessed 28 January 2014).

Trubek, D.M., Coutinho, D.R. and Schapiro, M.G. (2013) 'Toward a New Law and Development: New State Activism in Brazil and the Challenge for Legal Institutions', World Bank Legal Review 4, 2013, pp.281-314.

UNRISD (2010) Combating Poverty and Inequality: Structural Change, Social Policy and Politics. Geneva: UNRISD.

World Bank (2000-01) World Development Report: Attacking Poverty. Washington DC: World Bank.

World Bank (2009) Conditional Cash Transfers: Reducing Present and Future Poverty, http://documents.worldbank.org/curated/en/2009/01/10298306/conditional-cash-transfers-reducing-present-futurepoverty (accessed 31 January 2014). 


\section{Tables and Figures}

Table 1: Brazil: Number of beneficiaries of PBF and BPC and value of transfers, 2004-2013.

\begin{tabular}{|c|c|c|c|c|c|c|c|c|c|c|}
\hline & 2004 & 2005 & 2006 & 2007 & 2008 & 2009 & 2010 & 2011 & 2012 & 2013 \\
\hline PBF & $6,571,839$ & $8,700,445$ & $10,965,810$ & $11,043,076$ & $10,557,996$ & $12,370,915$ & $12,778,220$ & $13,352,306$ & $13,902,155$ & $14,086,199$ \\
\hline $\mathbf{R} \$ \mathrm{mn}$ & 440 & 549 & 687 & 831 & 906 & 1,174 & 1,239 & 1,602 & 2,013 & 2,139 \\
\hline$\%$ GDP & 0.23 & 0.26 & 0.29 & 0.31 & 0.30 & 0.36 & 0.33 & 0.39 & 0.46 & 0.45 \\
\hline BPC (for the aged) & 933,164 & $1,065,604$ & $1,183,840$ & $1,295,716$ & $1,423,790$ & $1,541,220$ & $1,623,196$ & $1,687,826$ & $1,750,121$ & $1,822,346$ \\
\hline BPC (for disability) & $1,127,849$ & $1,211,761$ & $1,293,645$ & $1,385,107$ & $1,510,682$ & $1,625,625$ & $1,778,345$ & $1,907,511$ & $2,021,721$ & $2,141,846$ \\
\hline $\mathbf{R} \$ \mathbf{m n}$ & 539 & 686 & 869 & 1,021 & 1,216 & 1,470 & 1,732 & 1,956 & 2,341 & 2,682 \\
\hline \% GDP & 0.28 & 0.32 & 0.37 & 0.38 & 0.40 & 0.45 & 0.46 & 0.47 & 0.53 & 0.56 \\
\hline
\end{tabular}

Sources: MDS, http://aplicacoes.mds.gov.br/sagi/FerramentasSAGI/index.php?group=1

Table 2: Brazil: Poverty and extreme poverty (individuals and \%)

\begin{tabular}{|c|c|c|c|c|c|c|c|c|c|c|}
\hline 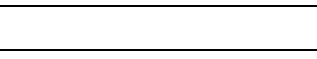 & 1990 & 1992 & 1993 & 1995 & 1996 & 1997 & 1998 & 1999 & 2001 & 2002 \\
\hline \multicolumn{11}{|l|}{ Poor } \\
\hline million & $58,119,829$ & $58,910,610$ & $60,944,462$ & $51,784,426$ & $51,800,588$ & $53,449,663$ & $52,070,300$ & $56,183,285$ & $58,291,560$ & $58,066,974$ \\
\hline$\%$ & 40.1 & 39.6 & 40.5 & 33.5 & 33.0 & 33.4 & 31.9 & 33.7 & 33.8 & 33.2 \\
\hline \multicolumn{11}{|l|}{ Extremely poor } \\
\hline million & $27,659,557$ & $27,954,489$ & $28,739,397$ & $22,430,610$ & $23,320,367$ & $23,676,733$ & $22,255,804$ & $23,954,701$ & $25,225,808$ & $23,596,581$ \\
\hline$\%$ & 19.1 & 18.8 & 19.1 & 14.5 & 14.8 & 14.8 & 13.6 & 14.4 & 14.6 & 13.5 \\
\hline$\%$ Poor households & 36.0 & 35.0 & 35.5 & 28.1 & 28.2 & 28.4 & 27.1 & 28.2 & 28.1 & 27.0 \\
\hline
\end{tabular}

\begin{tabular}{|c|c|c|c|c|c|c|c|c|c|}
\hline & 2003 & 2004 & 2005 & 2006 & 2007 & 2008 & 2009 & 2011 & 2012 \\
\hline \multicolumn{10}{|l|}{ Poor } \\
\hline million & $61,163,147$ & $59,558,144$ & $55,495,531$ & $48,539,284$ & $46,255,253$ & $41,507,735$ & $39,653,621$ & $33,958,884$ & $29,978,622$ \\
\hline$\%$ & 34.6 & 33.4 & 30.8 & 26.7 & 25.1 & 22.3 & 21.0 & 17.7 & 15.5 \\
\hline \multicolumn{10}{|l|}{ Extremely poor } \\
\hline million & $25,960,147$ & $23,356,695$ & $20,690,098$ & $17,157,720$ & $16,355,050$ & $13,888,528$ & $13,465,366$ & $11,636,688$ & $9,960,742$ \\
\hline$\%$ & 14.7 & 13.1 & 11.5 & 9.4 & 8.9 & 7.5 & 7.1 & 6.0 & 5.1 \\
\hline \% Poor households & 28.2 & 26.4 & 23.6 & 20.3 & 19.4 & 17.2 & 16.4 & 14.1 & 12.3 \\
\hline
\end{tabular}


Source: www.ipeadata.gov.br.

Table 3: Brazil: Federal transfers and public services, 1995-2010.

\begin{tabular}{|c|c|c|c|c|c|c|c|c|}
\hline & 1995 & 1996 & 1997 & 1998 & 1999 & 2000 & 2001 & 2002 \\
\hline \multicolumn{9}{|l|}{ Direct transfers } \\
\hline \% GDP & 7.6 & 7.7 & 7.8 & 8.6 & 8.6 & 8.8 & 9.2 & 9.3 \\
\hline$\%$ Transfers & 67.9 & 69.9 & 67.5 & 69.9 & 70.9 & 69.7 & 70.5 & 72.3 \\
\hline \multicolumn{9}{|l|}{ Public services } \\
\hline$\%$ GDP & 3.6 & 3.3 & 3.7 & 3.7 & 3.5 & 3.8 & 3.8 & 3.6 \\
\hline \% Transfers & 32.1 & 30.1 & 32.5 & 30.1 & 29.1 & 30.3 & 29.5 & 27.7 \\
\hline \multicolumn{9}{|l|}{ Total } \\
\hline$\%$ GDP & 11.2 & 11.0 & 11.5 & 12.3 & 12.2 & 12.6 & 13.0 & 12.9 \\
\hline \% Transfers & 100.0 & 100.0 & 100.0 & 100.0 & 100.0 & 100.0 & 100.0 & 100.0 \\
\hline
\end{tabular}

Source: Castro et al (2012, p.13) and Chaves and Ribeiro (2012, p.11).

Direct transfers: food and nutrition, social assistance, benefits to state employees and social security.

Public services: Culture, agrarian development, education, employment and worker protection, housing and urban development,

sanitation and health.

\begin{tabular}{|c|c|c|c|c|c|c|c|c|}
\hline & 2003 & 2004 & 2005 & 2006 & 2007 & 2008 & 2009 & 2010 \\
\hline \multicolumn{9}{|l|}{ Direct transfers } \\
\hline \% GDP & 9.7 & 9.8 & 10.2 & 10.5 & 10.3 & 10.0 & 10.6 & 10.8 \\
\hline \% Transfers & 74.6 & 74.1 & 73.8 & 72.8 & 71.5 & 70.6 & 68.5 & 69.7 \\
\hline \multicolumn{9}{|l|}{ Public services } \\
\hline \% GDP & 3.3 & 3.4 & 3.6 & 3.9 & 4.1 & 4.2 & 4.9 & 4.7 \\
\hline$\%$ Transfers & 25.4 & 25.9 & 26.2 & 27.2 & 28.5 & 29.4 & 31.5 & 30.3 \\
\hline \multicolumn{9}{|l|}{ Total } \\
\hline$\%$ GDP & 12.9 & 13.2 & 13.8 & 14.4 & 14.4 & 14.2 & 15.5 & 15.5 \\
\hline$\%$ Transfers & 100.0 & 100.0 & 100.0 & 100.0 & 100.0 & 100.0 & 100.0 & 100.0 \\
\hline
\end{tabular}


